\title{
INTERIM REPORT \\ U.S. Department of Energy \\ DIRECT INVESTIGATIONS OF THE IMMOBILIZATION OF RADIONUCLIDES IN THE ALTERATION PHASES OF SPENT NUCLEAR FUEL
}

\author{
Peter C. Burns (Principal Investigator) \\ Department of Civil Engineering and Geological Sciences \\ University of Notre Dame \\ Notre Dame, IN 46556-0767 \\ Robert J. Finch (Co-Investigator) \\ Argonne National Laboratory, Chemical Technology Division, 9700 South Cass Avenue, \\ Argonne, IL 60439-4837

\section{David J. Wronkiewicz (Co-Investigator)} \\ Department of Geology and Geophysics, University of Missouri-Rolla, Rolla, Missouri 65401 \\ Project Number: 59960 renewed as 73691 \\ Grant Number: DE-FG07-97ER14820 \\ Grant Project Officers: Nicholas Woodward \\ Project Duration: September 1997-September 2003
}




\section{TABLE OF CONTENTS}

EXECUTIVE SUMMARY 3

RESEARCH OBJECTIVES 4

METHODS AND RESULTS 5

Structural Characterization of Uranyl Phases (U. Notre Dame) 5

Theoretical Prediction of Incorporation Mechanisms for Fission Products (U. Notre Dame) 9 Investigation of Incorporation of $\mathrm{Pu}^{4+}$ and $\mathrm{Am}^{3+}$ into Uranyl Phases (U. Missouri) 10

Synthesis and Characterization of Ba Uranyl Molybdate (ANL) 11

Geochemical Behavior of Neptunium (ANL) 12

$\begin{array}{ll}\text { Synthesis of a New Np(VI) Nitrate (ANL) } & 12\end{array}$

Synthesis and Characterization of Np-Doped U Oxides (ANL) 12

Synthesis and Characterization Np-Doped U Oxyhydroxides (ANL) 12

Synthesis and Characterization Pure Np Silicates (ANL) 13

EXAFS of Lanthanide-Bearing Silicate (ANL) 13

Demonstration and Importance of Ion Exchange in Uranyl Phases (U. Notre Dame) 13

RELEVANCE AND IMPACT 14

PROJECT PRODUCTIVITY 16

PERSONNEL SUPPORTED (1997-2001) 16

$\begin{array}{ll}\text { PUBLICATIONS } & 17\end{array}$

Peer-Reviewed Archival Journal Publications 17

Refereed Symposium Proceedings 18

Refereed Conference Abstracts 19

$\begin{array}{ll}\text { Other Publications } & 20\end{array}$

Invited Lectures (Short Courses) 21

Invited Lectures (non-refereed) 21

Publication of RIM volume "Uranium: Mineralogy, Geochemistry and the Environment" 21

Publication of Scientific Basis for Nuclear Waste Management Volume 556 21

$\begin{array}{lr}\text { INTERACTIONS } & 22\end{array}$

Interactions with National Spent Fuel Program $\quad 22$

Collaborations with Russian Scientists $\quad 22$

Collaborations with University of Michigan $\quad 22$

FUTURE WORK 23

LITERATURE CITED 24 


\section{EXECUTIVE SUMMARY}

Safe disposal of the nation's nuclear waste in a geological repository involves unique scientific and engineering challenges owing to the very long-lived radioactivity of the waste. The repository must retain a variety of radionuclides that have vastly different chemical characters for several thousand years. Most of the radioactivity that will be housed in the proposed repository at Yucca Mountain will be associated with spent nuclear fuel, much of which is derived from commercial reactors [about 70,000 tons of $\mathrm{UO}_{2}$ (LWR) spent fuel by the year 2010]. DOE is custodian of approximately 8000 tons of spent nuclear fuel that is also intended for eventual disposal in a geological repository. Unlike the spent fuel from commercial reactors, the DOE fuel is diverse in composition with more than 250 varieties. Safe disposal of spent fuel requires a detailed knowledge of its long-term behavior under repository conditions, as well as the fate of radionuclides released from the spent fuel as waste containers are breached. Nine radionuclides are of special concern because of their long half-lives, radiological toxicities, and potential mobilities under repository conditions: Np-237, Pu-239, Pu-242, U-234, Pa-231, Tc-99, I-129, Se-79, and C-14. In addition, Am-241 is important because it is a parent of Np-237. An understanding of the behaviors of each of these ele ments under repository-relevant conditions is essential to safe disposal.

Laboratory-scale experiments using $\mathrm{UO}_{2}$ spent fuel, unirradiated $\mathrm{UO}_{2}$, and uranium metal indicate that spent fuels are unstable under the moist oxidizing conditions expected in the proposed repository at Yucca Mountain. The experimental results are consistent with studies of natural analogues that show significant alteration of uraninite (the mineral analogue of $\mathrm{UO}_{2}$ in spent fuel) under conditions similar to those expected in the proposed repository. Both vapor hydration and hydrologically unsaturated drip tests involving spent fuel have demonstrated that the alteration rates of the spent fuel will be appreciable under repository conditions, with the alteration products being mainly uranyl $\left(\mathrm{U}^{6+}\right)$ phases owing to the dominance of $\mathrm{U}$ in spent fuel. The alteration involves matrix dissolution of the spent fuel and thus provides a release path for radionuclides contained within. The results of our ongoing research have demonstrated that it is likely that the uranyl phases forming due to the alteration of spent fuel will incorporate many of the radionuclides contained in the spent fuel, thus having a profound impact upon the mobility of the radionuclides.

Our research to date involves several components designed to provide an understanding of the impact of uranyl phases on radionuclide mobility in a geological repository: (1) we have characterized the crystal structures and chemistries of 21 uranyl phases that are likely to form due to the alteration of spent fuel in the proposed repository, and developed a structural hierarchy for uranyl phases that aids prediction of their impact upon radionuclide mobility, (2) we have developed theoretical predictions of incorporation mechanisms for various radionuclides into uranyl phases that are likely to form under repository conditions, (3) we have verified selected predicted incorporation mechanisms by synthesis of uranyl phases containing the radionuclide of interest, (4) we have demonstrated ion exchange of radionuclides into the structures of single crystals of uranyl phases expected to form in the proposed repository, and (5) we have studied the structures and stabilities of various neptunyl and neptunyl-uranyl phases by phase synthesis and synchrotron experiments. These components, taken together, provide an enhanced understanding of the impact of uranyl phases on the release of radionuclides during the corrosion of spent fuel under the conditions of the proposed repository. Our studies have demonstrated that the solubilities of a number of important radionuclides will largely be controlled by their sorption onto, ion exchange with, or coprecipitation into various uranyl alteration phases. We have thus demonstrated that uranyl alteration phases may significantly retard radionuclide migration from waste forms in the proposed repository. 


\section{RESEARCH OBJECTIVES}

The safe disposal of the nation's nuclear waste in a geologic repository is one of the most significant and difficult scientific endeavors of the twenty-first century. Unique scientific challenges are posed by the very long-lived radioactivity of nuclear waste. Many radionuclides of vastly different chemical character must be retained by the repository for several thousand years. Some with longer half-lives, such as Pu-239 and Tc-99, need to be isolated for periods approaching a million years. In order to ensure the safety of a geologic repository, a detailed understanding of the mobility of radionuclides in complex natural systems is essential.

Most of the radioactivity in a geological repository will be associated with spent nuclear fuel. In the United States spent fuel is derived from several sources. The majority is $\mathrm{UO}_{2}$ (LWR) spent fuel from commercial reactors. About 30,000 metric tons of spent fuel was in storage at commercial reactors by 1995, with the expectation that this quantity will more than double by 2010 (Integrated Data Report 1995). All spent fuel derived from commercial reactors is intended for eventual disposal in a geological repository. In addition, the DOE is the custodian of about 8000 metric tons of spent fuel, most of which is also intended for disposal in a geological repository. Although there are more than 250 types of spent fuel in the DOE inventory, the fuels may be broadly classified into (1) uranium metal fuel, (2) aluminum-based fuel, (3) mixed oxide (MOX) fuel containing substantial plutonium, and (4) graphite fuel (Colleen Shelton-Davis, personal communications, January 2000).

Disposal of spent fuel in a geological repository requires detailed knowledge of the longterm behavior of the waste forms under repository conditions, as well as the fate of radionuclides released from the waste packages as containers are breached. The proposed Yucca Mountain repository is intended to hold 70,000 metric tons of high-level nuclear waste. Nine radionuclides considered in the TSPA-VA (Total System Performance Analysis - Viability Assessment) Base Case Performance Analysis (CRWMS, 1998, cf. Table 3-14 in section 3.5.1) are of special concern because of their long half-lives, radiological toxicities, and potential mobilities under repository conditions. These are five actinide isotopes, $\mathrm{Np}-237, \mathrm{Pu}-239, \mathrm{Pu}-242, \mathrm{U}-234$, and $\mathrm{Pa}-$ 231, and four fission products, Tc-99, I-129, Se-79, and C-14. In addition, Am-241 is important because it is a parent of Np-237. An understanding of the behaviors of these elements under repository-relevant conditions is essential to safe disposal.

Natural analogue studies of the mineral uraninite, $\mathrm{UO}_{2+x}$ (an analogue for $\mathrm{UO}_{2}$ in spent fuel), as well as several laboratory-scale simulations, confirm that spent fuel is unstable under the moist, oxidizing conditions expected in the proposed repository at Yucca Mountain. Once containers are breached, alteration of the spent fuel may be rapid, with the most abundant alteration products being uranyl $\left(\mathrm{U}^{6+}\right)$ phases. Shortly after groundwater or condensed water vapor contacts spent fuel in the proposed repository, uranyl phases are likely to be abundant in the vicinity of the spent fuel. Most of the uranyl phases that will form in the repository are already known as minerals from natural systems. Many of these uranyl phases can persist for thousands of years, as demonstrated by studies of natural analogues (Finch et al. 1996). It is likely that uranyl phases forming due to the alteration of spent fuel will incorporate many of the radionuclides contained in the spent fuel (Burns et al. 1997), thus having a profound impact upon the mobility of the radionuclides. Our ongoing research is leading to an understanding of the impact of incorporation of radionuclides into uranyl phases. Such information is essential to an understanding of the long-term performance of the geological repository.

Knowledge of the crystal structures, chemistries, stabilities and paragenesis of uranyl minerals lag far behind most other mineral groups, owing in large part to the occurrence of these minerals as complex intergrowths of multiple phases, making routine analysis very difficult. 
Studies of natural analogues and laboratory simulations have left little doubt that uranyl minerals will be very important alteration phases of spent nuclear fuel in the proposed repository at Yucca Mountain. As we have argued in many publications (see Literature Cited below), a detailed understanding of all aspects of these minerals is key to assessing their impact upon the release of radionuclides from the waste forms. Our research objectives include detailed characterization (structural and chemical) of uranyl compounds that are likely to form under repository conditions, the prediction of possible mechanisms of incorporation of radionuclides into their structures, and experimental verification of such incorporation.

\section{METHODS AND RESULTS}

This interim report summarizes work completed and in progress under projects 59960 and 73691 through March, 2001. Our work involves several components: (1) structural characterization of the uranyl phases that form due to the alteration of spent nuclear fuel, (2) theoretical predictions of incorporation mechanisms of radionuclides into uranyl phases, (3) synthesis of radionuclide-bearing uranyl phases to substantiate theoretical predictions, (4) investigations of ion exchange of radionuclides with uranyl phases, (5) studies of Np-bearing phases by synthesis and synchrotron studies. These components, taken together, provide an enhanced understanding of the impact of uranyl phases on the release of radionuclides during the corrosion of spent nuclear fuel.

Details of the work completed to date are summarized below. In brief, this research substantially improves understanding of how alteration phases of spent fuel will impact upon the release of radionuclides from a geological repository. As part of this project, we have characterized the crystal structures and chemistries of 21 uranyl phases that are likely to be important under repository conditions, as shown by laboratory simulations and studies of natural analogues. Prior to our research, most of these phases were very poorly characterized, with unknown structures and uncertain chemistries. We have developed a structural hierarchy for uranyl phases, and have used it as the basis for the prediction of incorporation mechanisms for various radionuclides into their structures. Following the development of synthesis techniques for uranyl phases, using non-radioactive surrogates, we have demonstrated that $\mathrm{Ce}^{4+}$ (surrogate for $\mathrm{Pu}$ ) and $\mathrm{Nd}^{3+}$ (surrogate for $\mathrm{Am}$ ) are incorporated into several uranyl phases. Our demonstration of ion-exchange properties of uranyl phases has opened up a new area of research in uranium mineralogy, which has important implications for repository performance.

\section{Structural Characterization of Uranyl Phases (U. Notre Dame)}

Prediction of incorporation mechanisms of radionuclides into uranyl phases that form due to alteration of spent fuel requires a detailed knowledge of the crystal structures of the uranyl phases. Determination of the structures of uranyl phases is difficult owing to the small size of the crystals, unusually complex structures and large unit cells, instability of crystals during lengthy exposure to X-rays, twinning, and the high absorption of X-rays by the crystals. As such, the structures and details of the chemistry of many of the uranyl phases relevant to repository performance were either unknown or only poorly characterized.

The recent introduction of the CCD-based detector of X-rays to mineral structure analysis (Burns 1998a) has permitted studies of the structures of many uranyl phases that were intractable using conventional detector systems mounted on a serial diffractometer. The CCD-based detector system utilizes a phosphor linked to a scientific-grade CCD chip via a fiber optics taper to provide a two-dimensional digital image of X-ray diffraction space. The detector provides 
substantially improved sensitivity, resolution and efficiency as compared to a conventional scintillation detector mounted on a serial diffractometer. The CCD detector thus permits the study of crystals that were too small, too unstable, or too complex for study with a conventional diffractometer. The newly determined structures of uranyl phases relevant to geologic disposal of spent fuel are summarized herein. The formulae of each are given in Table 2.

Table 2. Uranyl structures determined using a CCD-based detector system that are relevant to geologic disposal of spent fuel

\begin{tabular}{|c|c|c|}
\hline Mineral name & Formula & Reference \\
\hline Compreignacite & $\mathrm{K}_{2}\left[\left(\mathrm{UO}_{2}\right)_{3} \mathrm{O}_{2}(\mathrm{OH})_{3}\right]_{2}\left(\mathrm{H}_{2} \mathrm{O}\right)_{7}$ & Burns (1998c) \\
\hline Boltwoodite & $\left(\mathrm{K}_{0.56} \mathrm{Na}_{0.42}\right)\left[\left(\mathrm{UO}_{2}\right)\left(\mathrm{SiO}_{3} \mathrm{OH}\right)\right]\left(\mathrm{H}_{2} \mathrm{O}\right)_{1.5}$ & Burns (1998b) \\
\hline Weeksite & $\mathrm{K}_{2}\left(\mathrm{UO}_{2}\right)_{2} \mathrm{Si}_{6} \mathrm{O}_{15}\left(\mathrm{H}_{2} \mathrm{O}\right)_{4}$ & Jackson \& Burns (2001) \\
\hline Haiweeite & $\mathrm{Ca}\left[\left(\mathrm{UO}_{2}\right)_{2} \mathrm{Si}_{5} \mathrm{O}_{12}(\mathrm{OH})_{2}\right]\left(\mathrm{H}_{2} \mathrm{O}\right)_{3}$ & Burns (2001a) \\
\hline Agrinierite & $\mathrm{K}_{2}(\mathrm{Ca}, \mathrm{Sr})\left[\left(\mathrm{UO}_{2}\right)_{3} \mathrm{O}_{3}(\mathrm{OH})_{2}\right] 2.4 \mathrm{H}_{2} \mathrm{O}$ & Cahill \& Burns (2000) \\
\hline Umohoite & {$\left[\left(\mathrm{UO}_{2}\right) \mathrm{MoO}_{4}\left(\mathrm{H}_{2} \mathrm{O}\right)\right]\left(\mathrm{H}_{2} \mathrm{O}\right)$} & Krivovichev \& Burns (2000a) \\
\hline \multirow[t]{6}{*}{ Iriginite } & {$\left[\left(\mathrm{UO}_{2}\right) \mathrm{Mo}_{2} \mathrm{O}_{7}\left(\mathrm{H}_{2} \mathrm{O}\right)_{2}\right]\left(\mathrm{H}_{2} \mathrm{O}\right)$} & Krivovichev \& Burns (2000b) \\
\hline & $\mathrm{Na}_{6}\left[\left(\mathrm{UO}_{2}\right)_{2} \mathrm{O}\left(\mathrm{MoO}_{4}\right)_{4}\right]$ & Krivovichev \& Burns (2001a) \\
\hline & $\mathrm{Na}_{6}\left[\left(\mathrm{UO}_{2}\right)\left(\mathrm{MoO}_{4}\right)_{4}\right]$ & Krivovichev \& Burns (2001a) \\
\hline & $\mathrm{K}_{6}\left[\left(\mathrm{UO}_{2}\right)_{2} \mathrm{O}\left(\mathrm{MoO}_{4}\right)_{4}\right]$ & Krivovichev \& Burns (2001a) \\
\hline & $\mathrm{Cs}\left[\left(\mathrm{UO}_{2}\right)_{6}\left(\mathrm{MoO}_{4}\right)_{7}\left(\mathrm{H}_{2} \mathrm{O}\right)_{2}\right]$ & Krivovichev \& Burns (2001b) \\
\hline & $\mathrm{NH}_{4}\left[\left(\mathrm{UO}_{2}\right)_{6}\left(\mathrm{MoO}_{4}\right)_{7}\left(\mathrm{H}_{2} \mathrm{O}\right)_{2}\right]$ & Krivovichev \& Burns (2001b) \\
\hline Wyartite & $\mathrm{CaU}^{5+}\left(\mathrm{UO}_{2}\right)_{2}\left(\mathrm{CO}_{3}\right) \mathrm{O}_{4}(\mathrm{OH})\left(\mathrm{H}_{2} \mathrm{O}\right)_{7}$ & Burns \& Finch (1999) \\
\hline Bijvoetite & {$\left[(\mathrm{Y}, R E E)_{8}{ }^{3+}\left(\mathrm{UO}_{2}\right)_{16}\left(\mathrm{CO}_{3}\right)_{16} \mathrm{O}_{8}(\mathrm{OH})_{8}\left(\mathrm{H}_{2} \mathrm{O}\right)_{25}\right]\left(\mathrm{H}_{2} \mathrm{O}\right)_{14}$} & Li \& Burns (2000) \\
\hline \multirow[t]{2}{*}{ Grimsilite } & $\mathrm{K}_{3} \mathrm{Na}\left[\left(\mathrm{UO}_{2}\right)\left(\mathrm{CO}_{3}\right)_{3}\right]\left(\mathrm{H}_{2} \mathrm{O}\right)$ & Li \& Burns (2001) \\
\hline & $\mathrm{Na}_{4}\left(\mathrm{UO}_{2}\right)\left(\mathrm{CO}_{3}\right)_{3}$ & Li et al. (2001) \\
\hline \multirow[t]{5}{*}{ Uranopilite } & {$\left[\left(\mathrm{UO}_{2}\right)_{6}\left(\mathrm{SO}_{4}\right) \mathrm{O}_{2}(\mathrm{OH})_{6}\left(\mathrm{H}_{2} \mathrm{O}\right)_{6}\right]\left(\mathrm{H}_{2} \mathrm{O}\right)_{8}$} & Burns (2001) \\
\hline & $\mathrm{KNa}_{3}\left(\mathrm{UO}_{2}\right)_{2}\left(\mathrm{Si}_{4} \mathrm{O}_{10}\right)_{2}\left(\mathrm{H}_{2} \mathrm{O}\right)_{4}$ & Burns et al. (2000a) \\
\hline & $\mathrm{Cs}_{3}\left[\left(\mathrm{UO}_{2}\right)_{12} \mathrm{O}_{7}(\mathrm{OH})_{13}\right]\left(\mathrm{H}_{2} \mathrm{O}\right)_{3}$ & Hill \& Burns (1999a) \\
\hline & $\mathrm{K}_{5}\left[\left(\mathrm{UO}_{2}\right)_{10} \mathrm{O}_{8}(\mathrm{OH})_{9}\right]\left(\mathrm{H}_{2} \mathrm{O}\right)$ & Burns \& Hill (2000a) \\
\hline & $\mathrm{Sr}_{2.84}\left[\left(\mathrm{UO}_{2}\right)_{4} \mathrm{O}_{4}(\mathrm{OH})_{3}\right]_{2}\left(\mathrm{H}_{2} \mathrm{O}\right)_{2}$ & Burns \& Hill (2000b) \\
\hline
\end{tabular}

Compreignacite has been identified in the alteration phases of both unirradiated $\mathrm{UO}_{2}$ and $\mathrm{UO}_{2}$ spent fuel subjected to drip tests (Finch et al. 1999). However, the phase had only been poorly characterized, and the structure and exact chemical formula were unknown. Burns (1998c) reported a complete structure determination for compreignacite from the geologic type locality. The structure is based upon sheets of uranyl pentagonal bipyramids with the underlying protasite $\left(\alpha-\mathrm{U}_{3} \mathrm{O}_{8}\right)$ anion topology, which is known from several other uranyl minerals (Burns 1999a), with the $\mathrm{K}$ cation and $\mathrm{H}_{2} \mathrm{O}$ groups located in the interlayer.

Boltwoodite is the predominant alteration product of spent $\mathrm{UO}_{2}$ fuel in "drip" tests after only a few years (Finch et al. 1999) and is also an important alteration product of unirradiated $\mathrm{UO}_{2}$ in similar tests (Wronkiewicz et al. 1996). The structure was imperfectly known based on poorly refined data collected from a twinned crystal (Stohl \& Smith 1981). We obtained superb crystals from a natural specimen, and the structure was fully determined and reported in Burns (1998b). This work confirmed that the structure contained the $\alpha$-uranophane-type sheet, with Na and $\mathrm{K}$ cations located in the interlayer, together with $\mathrm{H}_{2} \mathrm{O}$ groups. The crystal studied contained approximately equal amounts of $\mathrm{K}$ and $\mathrm{Na}$, which were found to assume different positions in the interlayer.

Partial structure determinations were reported for the uranyl silicate weeksite by Stohl \& Smith (1981) and Baturin \& Sidorenko (1985). Weeksite is a common alteration product of 
actinide-bearing borosilicate waste glass (Burns et al. 2000a), and may form as a corrosion product of $\mathrm{UO}_{2}$ fuels where $\mathrm{Si}$ concentrations become sufficiently elevated (Wilson 1990), such as in the vicinity of altered glass. The structure of a natural crystal of weeksite has been fully determined and refined, with the results reported by Jackson \& Burns (2001). The structure contains unusual uranyl silicate layers involving bands of silicate tetrahedra. The layers are linked by vertex sharing of silicate tetrahedra, forming a framework with large interstitial sites where the low-valence cations and $\mathrm{H}_{2} \mathrm{O}$ groups are located.

Haiweeite, a Ca uranyl silicate, was identified as an alteration product of $\mathrm{UO}_{2}$ spent fuel in batch dissolution tests by Wilson (1990); additional dissolved Si in these experiments was derived from the partial dissolution of the Pyrex glass beakers. A partial structure determination had been reported by Rastsvetaeva et al. (1997) for a twinned microcrystal. The full structure of haiweeite was determined and refined, with the results reported in Burns (2001). The structure contains uranyl silicate sheets that are similar to those found as layers in weeksite, but in the case of haiweeite the sheets are not directly linked. Ca cations and $\mathrm{H}_{2} \mathrm{O}$ groups are located in the interlayer of the structure.

Agrinierite is the only natural Sr-bearing uranyl oxide hydrate mineral. Owing to its potential importance in explaining the retention of $\mathrm{Sr}$ in the drip tests performed for $\mathrm{UO}_{2}$ spent fuel (Finn et al.1999), we obtained crystals of agrinierite and determined the crystal structure and correct formula. The structure is reported in Cahill \& Burns (2000) and contains sheets of uranyl pentagonal bipyramids that are based upon the protasite $\left(\alpha-\mathrm{U}_{3} \mathrm{O}_{8}\right)$ sheet anion-topology. All lowvalence cations occur in the interlayer region, with $\mathrm{Sr}$ and $\mathrm{Ca}$ occurring at the same structural site.

The identification of the phase $\left(\mathrm{Cs}_{2 \mathrm{x}} \mathrm{Ba}_{1-\mathrm{x}}\right)\left[\left(\mathrm{UO}_{2}\right)_{5}\left(\mathrm{MoO}_{6}\right)(\mathrm{OH})_{6}\right] \cdot n \mathrm{H}_{2} \mathrm{O}(\mathrm{x} \sim 0.4, n \sim 6)$ in the alteration products of $\mathrm{UO}_{2}$ spent fuel from drip tests (Buck et al. 1997, Finch \& Buck 1998) demonstrates the importance of uranyl molybdate phases under repository conditions. We have undertaken an extensive examination of the structures of natural and synthetic uranyl molydates to develop an understanding of their crystal chemistry. A partial structure model for umohoite was reported by Anikina \& Makarov (1961) and Makarov \& Akinina (1963) using crystak from a Russian locality. We re-determined the structure using crystals from the same locality, but obtained substantially different results (Krivovichev \& Burns 2000a). The structure contains sheets of uranyl and molybdate polyhedra that are based upon the uranophane anion-topology, with $\mathrm{H}_{2} \mathrm{O}$ groups located in the interlayers. The sheets contain uranyl pentagonal bipyramids and distorted Mo $\phi_{6}$ octahedra, in contrast to the uranyl and molybdate hexagonal bipyramids reported from the earlier work. A redetermination of the structure of iriginite (Krivovihev \& Burns 2000b) confirmed most of the structure model provided by Serezhkin et al. (1981), although the space group found in the current study differed from the earlier study. Additional studies of the crystal chemistry of uranyl molybdates have given new structures of several uranyl molybdate compounds that have been reported by Krivovichev \& Burns (2001a,b). These structures demonstrate novel structural connectivities that may be significant in uranyl molybdates formed due to alteration of spent nuclear fuel under geological repository conditions.

The structure of the mixed-valence Ca uranyl carbonate wyartite was reported in Burns \& Finch (1999). Prior to the structure determination, wyartite was thought to contain $\mathrm{U}^{4+}$ and $\mathrm{U}^{6+}$. The structure determination indicated that the $\mathrm{U}$ was more likely present as $\mathrm{U}^{5+}$ and $\mathrm{U}^{6+}$, making wyartite the first mineral to contain structurally essential pentavalent uranium. The structure contains sheets of edge-sharing uranyl pentagonal bipyramids and pentagonal bipyramids that contain $\mathrm{U}^{5+}$. The $\mathrm{U}^{5+}$ polyhedra share an edge with a $\mathrm{CO}_{3}$ group, and Ca cations as well as $\mathrm{H}_{2} \mathrm{O}$ groups are located in the interlayer of the structure. 
The structure of several uranyl carbonates have been solved. That of bijvoetite was determined and reported by Li \& Burns (2000). Bijvoetite is a REE-bearing uranyl carbonate and its structure is very different from other uranyl carbonates. It contains sheets of edge- and vertexsharing uranyl pentagonal and hexagonal bipyramids, $\mathrm{CO}_{3}$ triangles, and Y,REE-bearing polyhedra. The interlayer of the structure contains only $\mathrm{H}_{2} \mathrm{O}$ groups. The structure of grimsilite was refined by Li \& Burns (2001), as it was only poorly known based upon studies done three decades ago. We also synthesized $\mathrm{Na}_{4}\left(\mathrm{UO}_{2}\right)\left(\mathrm{CO}_{3}\right)_{3}$ and determined its structure (Li et al. 2001). The structure contains the well-known uranyl tricarbonate cluster, but in a unique arrangement. It may be very significant under repository conditions, as it has been found as an alteration product of nuclear waste on Chernobyl "lava" (Burakov et al. 1999) and has recently been identified as a mineral in natural systems where uranium ore is altered (J. Cejka, personal communications, 2001).

The structure of the common uranyl sulfate uranopilite has resisted structure determination owing to the very small size of the crystals. The structure has been determined and exhibits a novel uranyl sulfate chain consisting of clusters of six edge-sharing uranyl pentagonal bipyramids linked through vertex sharing with sulfate tetrahedra (Burns 2001b). Uranopilite is important for determining the release of uranium from acidic mine tailings that are rich in sulfate, and is common in many uranium deposits in the United States and elsewhere.

A new uranyl silicate was discovered growing on actinide-bearing borosilicate waste glass that was held at $200^{\circ} \mathrm{C}$ for 60 days in $100 \%$ relative humidity by Burns et al. (2000a). Determination of the structure revealed that it involves novel sheets of vertex-sharing silicate tetrahedra with four- and eight-membered rings of tetrahedra. The silicate sheets are linked to form a framework by sharing vertices with uranyl square bipyramids. The framework contains channels in which $\mathrm{K}$ and $\mathrm{Na}$ cations occur, together with $\mathrm{H}_{2} \mathrm{O}$ groups.

In the course of investigations of $\mathrm{Cs}$ substitution into the interlayer sites of uranyl oxide hydrates, crystals of the phase $\mathrm{Cs}_{3}\left[\left(\mathrm{UO}_{2}\right)_{12} \mathrm{O}_{7}(\mathrm{OH})_{13}\right]\left(\mathrm{H}_{2} \mathrm{O}\right)_{3}$ were obtained and the structure was determined (Hill \& Burns 1999a). The structure contains sheets of edge-sharing uranyl pentagonal bipyramids based upon the protasite $\left(\alpha-\mathrm{U}_{3} \mathrm{O}_{8}\right)$ sheet anion-topology, with the $\mathrm{Cs}$ cations and $\mathrm{H}_{2} \mathrm{O}$ groups located in the interlayer. Owing to its structural similarity to compreignacite, a $\mathrm{K}$ uranyl oxide hydrate with the same sheet that has been found as an alteration product of $\mathrm{UO}_{2}$ spent fuel subjected to drip tests, it is possible that $\mathrm{Cs}_{3}\left[\left(\mathrm{UO}_{2}\right)_{12} \mathrm{O}_{7}(\mathrm{OH})_{13}\right]\left(\mathrm{H}_{2} \mathrm{O}\right)_{3}$ will form under repository conditions, impacting the mobility of ${ }^{135} \mathrm{Cs}$.

During synthesis experiments intended to grow boltwoodite, the new phase $\mathrm{K}_{5}\left[\left(\mathrm{UO}_{2}\right)_{10} \mathrm{O}_{8}(\mathrm{OH})_{9}\right]\left(\mathrm{H}_{2} \mathrm{O}\right)$ was obtained. Burns \& Hill (2000a) reported its unusual structure, which is based upon complex sheets of edge and vertex-sharing uranyl square and pentagonal bipyramids, with the $\mathrm{K}$ cations and $\mathrm{H}_{2} \mathrm{O}$ groups in the interlayer. The sheet of polyhedra is considerably more complex than is typically observed. The corresponding sheet anion-topology contains the first example of a novel chain-stacking sequence, and as such provides new insight into the topologies of the structures of uranyl phases.

Synthesis of the $\mathrm{Sr}$ analogue of curite (a $\mathrm{Pb}$ uranyl oxide hydrate), with formula $\mathrm{Sr}_{2.84}\left[\left(\mathrm{UO}_{2}\right)_{4} \mathrm{O}_{4}(\mathrm{OH})_{3}\right]_{2}\left(\mathrm{H}_{2} \mathrm{O}\right)_{2}$, was achieved, with the structure reported by Burns \& Hill (2000b). The close similarity of the ionic radii of $\mathrm{Sr}^{2+}$ and $\mathrm{Pb}^{2+}$ is presumably reflected in this isostructural pair. This phase may be responsible for retarding $\mathrm{Sr}$ in the alteration phases of $\mathrm{UO}_{2}$ spent fuel in drip tests, as observed by Finn et al. (1999). 
Current research concerning the structures of uranyl phases is focusing on uranyl carbonates, uranyl phosphates, uranyl silicates, uranyl sulfates, and uranyl oxide hydrates. We have obtained approximately a dozen additional structures of uranyl phases that are significant to geological disposal of nuclear waste, and are currently preparing manuscripts for submission to archival journals. In addition, we are expanding the structural hierarchy of Burns et al. (1996) and Burns (1999a) to reflect the more than 30 new uranyl structures that we have determined over the past three years. The insight into the crystal chemistry of uranium is proving very valuable in building an understanding of how spent nuclear fuel will alter in a geological repository such as Yucca Mountain, and how the uranyl phases that form due to such alteration will impact upon the release of radionuclides. A fundamental understanding of the crystal chemistry of uranium, and the structural hierarchy of uranium minerals and inorganic compounds, is the underpinning of our entire research program concerning the long-term behavior of spent nuclear fuel and the release of radionuclides from the near field in a geological repository setting.

\section{Theoretical Prediction of Incorporation Mechanisms for Fission Products (U. Notre Dame)}

Fission products such as Se-79 $\left(\mathrm{t}^{1 / 2}=1.1 \times 10^{6} \mathrm{yrs}\right.$. $)$ and Tc-99 $\left(\mathrm{t}^{1 / 2}=2.13 \times 10^{5} \mathrm{yrs}\right.$. $)$ are of considerable significance to geological disposal of spent fuel owing to their long half lives and their potentially high mobility in natural systems. Chen, Burns \& Ewing (1999a) examined the geochemical and crystallo-chemical retardation mechanisms for Se-79 under conditions similar to those expected in the proposed repository at Yucca Mountain. Under such conditions, $\left(\mathrm{SeO}_{3}\right)^{2-}$ (selenite) and $\left(\mathrm{SeO}_{4}\right)^{2-}$ (selenate) are the dominant aqueous species. Because of the high solubility of metal selenites and selenates, and the low adsorption of selenite and selenate aqueous anions by geological materials under repository conditions, Se may be highly mobile. However, consideration of the crystal chemistry of uranyl phases that form due to the alteration of spent fuel under repository conditions indicates that the Se may be incorporated into some of these phases in small quantities, thereby potentially reducing the mobility of Se. Chen et al. (1999a) noted that selenite will be the dominant aqueous form of Se where spent fuel is being altered to uranyl phases. The $\mathrm{Se}^{4+}$ cation is electron lone-pair stereoactive, resulting in a onesided $\mathrm{SeO}_{3}$ coordination polyhedron (a pyramid with the $\mathrm{Se}^{4+}$ cation at the apex and the base formed by three $\mathrm{O}$ atoms). The base of the pyramid has a similar geometry to $\mathrm{SiO}_{4}$ tetrahedra that occur in many of the uranyl phases. In some structures, such as soddyite, all apices of the $\mathrm{SiO}_{4}$ tetrahedron are structurally essential, thereby precluding the substitution of selenite for the $\mathrm{SiO}_{4}$ tetrahedron. However, in several uranyl silicates with structures based upon sheets of edge and vertex-sharing uranyl and silicate polyhedra, one apex of the $\mathrm{SiO}_{4}$ tetrahedron is not bonded within the sheet, and only participates in weak bonds with interlayer constituents. In these cases the substitution of selenite for $\mathrm{SiO}_{4}$ may occur.

Chen, Burns \& Ewing (2000) examined possible incorporation mechanisms for Tc-99 into the structures of uranyl phases. Under the conditions of spent fuel alteration to uranyl phases, the dominant oxidation state of Tc will be $7+$, with the aqueous species being $\left(\mathrm{TcO}_{4}\right)^{-1}$. The bonds within this tetrahedron are very strong, with $1.75 v u$ associated with each. As a result, the anions have most of their bonding requirements met by the bond to Tc, making it very unlikely that the $\left(\mathrm{TcO}_{4}\right)^{-1}$ group shares anions with other cations of high valence in a crystal structure. As such, it seems unlikely that Tc will be incorporated into the uranyl phases that form due to the alteration of spent fuel, a conclusion that is in accord with the observation of Finn et al. (1999) that Tc is steadily released from spent fuel during hydrologically unsaturated drip tests. 


\section{Investigation of Incorporation of $\mathrm{Pu}^{4+}$ and $\mathrm{Am}^{3+}$ into Uranyl Phases (U. Missouri)}

The potential for the incorporation of $\mathrm{Pu}^{4+}$ and $\mathrm{Am}^{3+}$ into uranyl alteration phases has been evaluated using $\mathrm{Ce}^{4+}$ and $\mathrm{Nd}^{3+}$ as surrogate elements for the actinides. The crystatchemical behavior of the lanthanides and actinides are expected to be comparable due to the similarity of their valence charges and ionic radii (e.g., $\mathrm{Ce}^{4+} 0.94 \AA$ vs. $\mathrm{Pu}^{4+} 0.93 \AA$; $\mathrm{Nd}^{3+} 1.04 \AA$ vs. $\mathrm{Am}^{3+} 1.07$ $\AA$ ). Crystalline phases were synthesized in these experiments by saturating solutions with U, plus various combinations of alkali elements, alkaline earths, $\mathrm{Si}, \mathrm{Ce}$ and/or $\mathrm{Nd}$ at temperatures between 90 to $185^{\circ} \mathrm{C}$. An analysis of the initial and final solutions, and solid-phase reaction products (after dissolution in a nitric acid solution) was performed using Inductively Coupled Plasma - Mass Spectroscopy (ICP-MS) analysis. A Scanning Electron Microscope (SEM) equipped with an Energy Dispersive X-ray Spectrometer (EDS) and an Analytical Electron Microscope (AEM) with an Energy Electron Loss Spectrometer (EELS) were used to characterize the morphology, composition, and structures of the solid phases.

Dehydrated schoepite was produced by dissolving uranyl oxyacetate into an aqueous solution containing either $2.1 \mathrm{ppm}$ Ce or $286 \mathrm{ppm} \mathrm{Nd}$. An analysis of the solids indicated a concentration of Ce that decreased from 26, to 20, and finally $11 \mathrm{ppm}$ for crystals produced in 7 , 35 , and 190-day experiments, respectively. The corresponding $\mathrm{K}_{d}$ values (solid

concentration/solution concentration) for these experiments were 12, 9.5, and 5.2. The pattern of decreasing Ce content is correlated with a progressive increase in grain size, with the 190-day experiments displaying the formation of the largest crystals. The $\mathrm{K}_{d}$ values for Ce retention thus appear to decrease as a function of decreasing surface area/volume ratios of the crystals. Such a trend suggests that Ce sorption followed by incorporation is favored at the higher-energy defect sites located at edges and/or surfaces of the dehydrated schoepite crystals. Experiments with $\mathrm{Nd}$ and dehydrated schoepite indicate an overall concentration of $1240 \mathrm{ppm}$ in the seven-day experiments and 920 ppm after 35 days. However, a heterogeneous distribution of $\mathrm{Nd}$ was noted during the AEM/EELS examination of these samples, suggesting that a separate Nd-rich solid phase had precipitated.

Ianthinite was obtained by dissolving uranyl oxyacetate in a solution containing $\mathrm{Cu}$ acetate monohydrate as a reductant. Ianthinite is of special interest with respect to actinide retention because it contains both $\mathrm{U}^{4+}$ and $\mathrm{U}^{6+}$ ions in its crystal structure. This phase thus has the potential to directly incorporate tetravalent actinide ions without the necessity of a chargecoupled substitution to balance the charge. Ianthinite is also expected to precipitate at the redox front between oxidized aqueous fluids and the reduced $\mathrm{UO}_{2}$ spent fuel matrix, thus it is likely to be the first alteration phase that any released actinides from spent fuel may encounter. The solutions used in the ianthinite experiments were doped with either $2.1 \mathrm{ppm}$ Ce or $399 \mathrm{ppm} \mathrm{Nd}$. The solid phase reaction products contained approximately $306 \mathrm{ppm}$ Ce after seven days, with the concentrations increasing to $334 \mathrm{ppm}$ after 35 days $\left(\mathrm{K}_{d} \mathrm{~s}=146\right.$ and 159 , respectively). Neodymium contents were approximately $24,800 \mathrm{ppm}\left(\mathrm{K}_{d}=62\right)$ after seven days in solution (Fig. 10). Solid phase examinations using AEM/EELS indicate a uniform distribution of $\mathrm{Nd}$ in the ianthinite crystals, while Ce contents (determined from ICP/MS analysis of the dissolved solids) were below detection limits for this instrument.

Becquerelite was produced by dissolving $\mathrm{U}$ oxyacetate and $\mathrm{Ca}$ acetate into solution. The solution in these experiments was doped with either $2.1 \mathrm{ppm}$ Ce or $277 \mathrm{ppm}$ Nd. ICP-MS results indicate that about $33 \mathrm{ppm} \mathrm{Ce}\left(\mathrm{K}_{d}=16\right)$ was incorporated into becquerelite, whereas Nd contents were higher, being approximately $1,300 \mathrm{ppm}\left(\mathrm{K}_{d}=4.7\right)$. A homogeneous distribution of $\mathrm{Nd}$ was 
noted in the solid phase during AEM/EELS examination, while Ce contents were below the limits of detection for this instrument.

The results of these experiments demonstrate the precipitation of significant quantities of both $\mathrm{Ce}^{4+}$ and $\mathrm{Nd}^{3+}$ with dehydrated schoepite, ianthinite, and becquerelite. By analogy, it is likely that $\mathrm{Pu}^{4+}$ and $\mathrm{Am}^{3+}$ behave in a similar fashion. The highest $\mathrm{K}_{\mathrm{d}}$ values obtained for both $\mathrm{Ce}^{4+}$ and $\mathrm{Nd}^{3+}$ are for ianthinite, which is consistent with earlier predictions (Burns et al. 1997) based upon the structure of ianthinite.

Sodium-compreignacite $\left(\mathrm{Na}_{2}\left(\mathrm{UO}_{2}\right)_{6} \mathrm{O}_{4}(\mathrm{OH})_{6}\left(\mathrm{H}_{2} \mathrm{O}\right)_{7}\right)$ tests were conducted at various $\mathrm{pH}$ values to assess the potential influence that $\mathrm{pH}$ may have on surface adsorptive properties. An analysis of the solids indicates a cerium concentration in the solids that increased from 272 , to 370 , and finally $796 \mathrm{ppm}$ for seven-day tests conducted at $\mathrm{pH}$ values of 4.2, 4.7, and 5.2, respectively. The corresponding $\mathrm{K}_{d}$ values were 30,35 , and 96 . The high $\mathrm{K}_{d}$ values displayed by the Na-compreignacite may have important implications for limiting the mobility of transuranic and lanthanide radionuclides because the relatively high Na content of the Yucca Mountain groundwater ( $\sim 50 \mathrm{ppm})$ should lead to abundant growth of Na-compreignacite alteration phases on spent nuclear fuel. Crystalline grain sizes were also noted to vary with $\mathrm{pH}$, with the smallest crystals occurring in tests with the highest $\mathrm{pH}$ values. Grain size may also influence the adsorptive capacity of the solid, with the smallest crystals having a highest proportion of crystalline defect sites, hence allowing a higher proportion of cerium substitution.

The incorporation of $\mathrm{Ce}^{4+}$ into crystalline boltwoodite $\left(\mathrm{K}\left(\mathrm{UO}_{2}\right)\left(\mathrm{SiO}_{3} \mathrm{OH}\right)\left(\mathrm{H}_{2} \mathrm{O}\right)_{1.5}\right)$ was limited compared to the patterns displayed by other uranium compounds. Approximately 7.0 ppm cerium was detected in crystals that formed from a solution with a corresponding cerium concentration of $1.8 \mathrm{ppm}$ after seven days. The resultant $\mathrm{K}_{d}$ value of 4 is considerably less that those displayed by other non-silicate uranium phases. Neodymium incorporation, however, appeared to be relatively high. Crystals that formed from a solution with a neodymium concentration of $2.6 \mathrm{ppm}$ contained $207 \mathrm{ppm}$ after seven days of testing. The resultant $\mathrm{K}_{d}$ value was 80 .

\section{Synthesis and Characterization of Ba Uranyl Molybdate (ANL)}

Buck et al. (1997) discovered a new Cs and Ba uranyl molybdate phase growing on $\mathrm{UO}_{2}$ spent fuel from hydrologically unsaturated drip tests. Experiments on the synthesis of the phase in the present study produced small crystals, precipitated from aqueous solutions made from the oxides, $\mathrm{UO}_{3}, \mathrm{MoO}_{3}$, and $\mathrm{BaO}$, after two to twenty weeks of reaction at $90^{\circ} \mathrm{C}$. However, these crystals were noted to dissolve when reacted for longer times at $90^{\circ} \mathrm{C}$. Transmission electron microscopic examinations of the crystals reveal that they are structurally similar to the Cs- and Ba-containing crystals formed during the corrosion of spent nuclear fuels. Efforts to reproduce the results at $90^{\circ} \mathrm{C}$ have not been successful; however, subsequent syntheses at $150^{\circ} \mathrm{C}$ produced larger crystals, for which chemical and structural analyses are in progress. Efforts to synthesize a Cs end member, nominally $\mathrm{Cs}_{2}\left(\mathrm{UO}_{2}\right)_{5}\left(\mathrm{MoO}_{6}\right)(\mathrm{OH})_{6}\left(\mathrm{H}_{2} \mathrm{O}\right)_{n}$, under conditions identical to those used to synthesize crystals of the $\mathrm{Ba}$ end member have not yet been successful, and attempts are still underway to synthesize the expected solid solution series with variable ratios of Cs:Ba. Potassium-bearing crystals have been synthesized at $150^{\circ} \mathrm{C}$; chemical and structural analyses of these crystals are currently in progress. 


\section{Geochemical Behavior of Neptunium (ANL)}

Work at Argonne on synthesizing uranyl compounds is ongoing, with considerable effort being made towards synthesizing and characterizing pure Neptunium $(\mathrm{Np})$ compounds and $\mathrm{Np}$ containing uranyl compounds. Np-containing U(VI) compounds are especially relevant to understanding potential geochemical behavior of $\mathrm{Np}$ in the presence of $\mathrm{U}$, such as expected where spent $\mathrm{UO}_{2}$ fuel undergoes aqueous corrosion in a high-level nuclear-waste repository. Efforts here consisted primarily of synthesizing and characterizing several new Np-bearing compounds, including preparation of a pure $\mathrm{Np}$ nitrate, a mixed $\mathrm{Np} / \mathrm{U}$ nitrate, several mixed $\mathrm{Np} / \mathrm{U}$ oxides and oxyhydroxides, and two mixed $\mathrm{Np} / \mathrm{U}$ silicates, as well as developing enhanced capabilities for analyzing samples containing multiple actinides by EXAFS.

\section{Synthesis of a New Np(VI) Nitrate (ANL)}

A $\mathrm{Np}(\mathrm{VI})$ nitrate has been prepared by evaporating aqueous solutions to dryness at approximately $100^{\circ} \mathrm{C}$ in air, which produces macroscopic crystals. The oxidation state of $\mathrm{Np}$ in this nitrate is $\mathrm{Np}(\mathrm{VI})$, as determined by opticalabsorption spectroscopy. The composition of the $\mathrm{Np}(\mathrm{VI})$ nitrate is still being investigated, but preliminary results indicate a $\mathrm{Np}$-to-nitrate ratio of 1:3; the compound is hydrated, with an undetermined number of $\mathrm{H}_{2} \mathrm{O}$ groups. Crystals are bright red, deliquescent, and alter readily in air, presumably by hydrating further (although this remains to be demonstrated). These properties are consistent with a synthetic amorphous $\mathrm{Np}$ nitrate reported in the literature. Our synthetic $\mathrm{Np}(\mathrm{VI})$ nitrate is crystalline, however, and may be a new compound. X-ray diffraction data collected from the compound do not match any known Np nitrates listed in the latest Powder Diffraction File (International Center for Diffraction Data). Most XRD patterns collected so far suggest a mixture of two or more phases in variable proportions.

\section{Synthesis and Characterization of Np-Doped U Oxides (ANL)}

Mixed Np/U anhydrous oxides have been synthesized with a range of Np:U ratios, and these are currently being analyzed by XRD and EXAFS/XANES. Initial results indicate several structural modifications as a function of the Np:U ratio, including a change in the local $\mathrm{Np}$ coordination environment (indicated by EXAFS) and an apparent phase transformation (indicated by XRD). Results are preliminary and examination of these oxides is continuing.

\section{Synthesis and Characterization Np-Doped U Oxyhydroxides (ANL)}

Several Np-bearing U(VI) and pure Np oxyhydroxides have been synthesized. XRD data indicate only slight changes to the unit-cell parameters with increasing $\mathrm{Np}$ concentrations in the $\mathrm{U}(\mathrm{VI})$ oxyhydroxides, up to approximately 20 mole $\% \mathrm{~Np}$. This is consistent with a solid solution between $\mathrm{U}(\mathrm{VI})$ oxyhydroxides and the isostructural $\mathrm{Np}(\mathrm{VI})$ oxyhydroxides, and suggests that the Np occurs as $\mathrm{Np}(\mathrm{VI})$ in these solids. These solids have not yet been analyzed by EXAFS/XANES, which should unambiguously determine the Np valence in these solids. 


\section{Synthesis and Characterization Pure Np Silicates (ANL)}

Two Np-bearing silicates were prepared by evaporating aqueous solutions to dryness at approximately $100^{\circ} \mathrm{C}$ in air. One of the solids prepared by this method is crystalline and, based on preliminary XRD data, may be structurally related to the uranophane group minerals; a second solid prepared in a similar fashion is amorphous, although chemically homogeneous. The $\mathrm{Np}$ oxidation state in both silicates appears to be $\mathrm{Np}(\mathrm{VI})$, as suggested by XANES; however, these results are somewhat ambiguous and more complete characterization is required.

Despite repeated efforts to synthesize pure $\mathrm{Np}$ silicates by more conventional hydrothermal methods known to successfully prepare uranyl silicates, no positive results have yet been obtained.

\section{EXAFS of Lanthanide-Bearing Silicate (ANL)}

Lanthanides are useful, nonradioactive chemical analogues of many actinides of environmental concern, so we have also been examining solid-state structural effects of lanthanide substitutions in synthetic crystals of zircon $\left(\mathrm{ZrSiO}_{4}\right)$. A major part of this effort is aimed at developing our capabilities for collecting EXAFS data from compounds with elements that may experience absorption-edge interferences from neighboring elements, as is the case for many actinides and lanthanides. Furthermore, nonradioactive lanthanides provide useful surrogates for examining structural changes induced by substitutions of actinides into crystalline materials, such as $\mathrm{ZrSiO}_{4}$. Recent efforts at Argonne have focused on examining REE substitutions by XRD and XAS.

\section{Demonstration and Importance of Ion Exchange in Uranyl Phases (U. Notre Dame)}

Ion exchange is common in minerals such as zeolites and some clays. Prior to our research, ion exchange had not been demonstrated for single crystals of a uranyl mineral. Some studies had suggesting ion exchange was possible in these structures, but in each case the procedure involved converting fine powders of one mineral to another by treatment with a solution containing dissolved ions. In these experiments, a solution-reprecipitation mechanism could not be ruled out.

Using single crystals of natural boltwoodite, Burns (1999c) demonstrated the exchange of Cs into the interlayer. These experiments were done using a few crystals with maximum dimensions of $\sim 200 \mu \mathrm{m}$. The crystals were recovered after treatment with a concentrated $\mathrm{CsCl}$ solution at $90^{\circ} \mathrm{C}$ (14 days) and $180^{\circ} \mathrm{C}(24$ hours). The crystals remained intact, with well-defined faces and sharp edges, thereby ruling out a solution-reprecipitation mechanism of exchange. Single-crystal structure determinations for crystals before and after the experiments showed that essentially all of the $\mathrm{Na}$ and $\mathrm{K}$ contained in the interlayer of the crystals was replaced by $\mathrm{Cs}$, as demonstrated by the substantial increase in the electron density in the interlayer.

The exchange of Cs into boltwoodite reported by Burns (1999c) is the first demonstrated ion exchange in single crystals of a uranyl phase, and has significant implications for the mobility of Cs under repository conditions. Additional experiments performed using synthetic boltwoodite demonstrated ion exchange of Cs into the structure where Cs was present in solution at concentrations of $\sim 100 \mathrm{ppm}$ (Hill \& Burns 1999b). These results indicate that minerals such as boltwoodite are likely to incorporate Cs-135 into their structures as they grow under repository 
conditions. Such phases are also likely to exchange ions with solutions that contact them after they grow, and may either sequester Cs or release it, depending upon the relative activities of different ions in the solution.

Recently we have completed similar experiments involving Cs exchange into single crystals of natural compreignacite. Again, single crystals were used that were recovered following exchange in concentrated solutions of $\mathrm{CsCl}$, with the crystals remaining intact with sharp faces and edges. Single-crystal X-ray diffraction studies of the crystals before and after the exchange experiments showed that the $\mathrm{K}$ in the interlayers of the crystals was largely replaced by Cs.

\section{RELEVANCE AND IMPACT}

The key process needs identified for the spent nuclear fuel Total System Performance Assessment models are an understanding of 1) the rates of container and spent fuel cladding failure, 2) the rates and mechanisms of spent fuel corrosion, and 3) the aqueous solubility of radionuclide species in the near-field waste package environment. The Total System Performance Assessment approach for modeling the repository behavior of spent nuclear fuel will be to develop a semi-empirical function for dissolution rates, uncertainties of these rates, and variations of these parameters as a function of temperature, total carbonate concentration, and $\mathrm{pH}$ ranges expected in the near-field repository environment.

The role that waste-form alteration phases have on limiting radionuclide solubilities can be an important component of Total System Performance Assessment models. The rationale for such an approach has been demonstrated in earlier studies of mineral paragenetic trends and the presence of trace components in phases formed during the weathering of naturally occurring uraninite (Frondel 1956, Finch \& Ewing 1992, Pearcy et al. 1994) or in the alteration of synthetic $\mathrm{UO}_{2}$ pellets (Wronkiewicz et al. 1992, 1996). Uranyl phases are expected to be the dominant alteration product during spent nuclear fuel corrosion, with the long-term prognosis suggesting the eventual complete replacement of the spent fuel $\mathrm{UO}_{2}$ and/or uranium metal waste form matrix by uranyl alteration phases (Wronkiewicz et al. 1996). The incorporation of radionuclides into solid alteration phases can immobilize and isolate them from the biosphere. This incorporation can be accomplished in any of several ways, including coprecipitation of radionuclides within the crystalline structures of uranyl phases, adsorption of radionuclides onto a relatively static surface of a solid phase, and incorporation of an adsorbed surface species within the crystalline structure of a host solid through a surface overgrowth process. The incorporation of a variety of fission product and transuranic radionuclides by crystalline structures of $U$ alteration phases has been the focus of much of our research to date.

Our studies have demonstrated that the solubilities of a number of important radionuclides (or their appropriate surrogate elements) will be controlled by their sorption onto, ion exchange with, or coprecipitation into various uranyl alteration phases. The "sequestering" of radionuclides by alteration phases may thus significantly retard radionuclide migration (as soluble components) from the near-field waste package environment.

If sufficient data are not available for performance assessment modeling of the solubility of radionuclides in the presence of a realistic suite of solid alteration phases, then a more conservative Total System Performance Assessment approach to release calculations will be required. Two potential approaches for this process currently exist. The first employs a spent fuel source term value (i.e., the dissolution rate of spent fuel) as a maximum near-field release 
rate for all radionuclide species present in the spent fuel. Studies concerned with commercial spent fuel alteration processes, however, suggest that spent nuclear fuel reaction rates may be quite rapid in a "Yucca Mountain-type" oxidized-unsaturated environment (Finn et al. 1996, Wronkiewicz et al. 1996). Thus, radionuclide release rates based upon such a scenario may be unacceptably high. The second method would employ experimentally determined solubility limits based upon results from experiments conducted in simplified chemical systems. An example of such an experiment can be found in the studies of Nitsche et al. $(1993,1995)$, where $\mathrm{Np}$ solubility was determined to be between $2.5 \times 10^{-3}$ to $2.7 \times 10^{-5} \mathrm{M}$ when controlled by $\mathrm{NaNpO}_{2} \mathrm{CO}_{3} \cdot\left(3.5 \mathrm{H}_{2} \mathrm{O}\right)$. The $\mathrm{Np}$ solubility limits imposed by this phase, however, far exceed $\mathrm{Np}$ concentrations observed during corrosion experiments with spent fuel. For example, Finn et al. (1994) measured dissolved $\mathrm{Np}$ concentrations of $9.3 \times 10^{-8} \mathrm{M}$ in leachates from spent fuel corrosion tests where schoepite and soddyite were identified. Subsequently, Buck et al. (1998) identified Np in dehydrated schoepite that had precipitated on the surface of spent fuel in similar tests with fuel exposed to saturated water vapor, and reported concentrations of $\sim 550 \mathrm{ppm}$ in the dehydrated schoepite. These combined results suggest that the concentration of $\mathrm{Np}$ may be controlled by its incorporation as a trace constituent in dehydrated schoepite rather than in a sodium-neptunyl carbonate, in which $\mathrm{Np}$ is a principal component.

The use of overly conservative solubility limits in the Total System Performance Assessment models may lead to predictions of unreasonably high release rates for isotopes such as Np-237. Such predictions could require the development and implementation of additional engineered barriers designed on the premise of unrealistic predictions of radionuclide release. Such a process could, at best, lead to a significant increase in the cost of a repository disposal system through an over engineered barrier system; and at worse, lead to a failed viability and/or licensing assessment process due to predictive models that determine release rates of radionuclides that will exceed the allowable regulatory limits. An accurate assessment of the solubilities of various radionuclides is essential for the development of a cost-effective engineered barrier system.

If the effect that uranyl phases are to have on fission product migration is to be included in future performance assessment models, then we will need to continue to improve our understanding of the compositional variations of these phases, their stability at various temperatures and fluid compositions, the identities of phases that help control element solubilities, and partition coefficients that govern the incorporation of trace amounts of radionuclides into crystal structures. We have made progress in each of these areas, and continue to focus our research efforts on these problems. 


\section{PROJECT PRODUCTIVITY}

We have accomplished many of the goals of our original proposed research (please see list of archival journal publications below), and have developed new goals on the basis of these results that constitute our ongoing research.

\section{PERSONNEL SUPPORTED (1997-2001)}

PIs:

Prof. Peter C. Burns, University of Notre Dame

Prof. David J. Wronkiewicz, University of Missouri-Rolla

Dr. Robert Finch, Argonne National Laboratory

\section{Post-Doctoral Fellows}

University of Notre Dame

Dr. Frances Hill (1997-1999, now a post-doc at Rutgers University)

Dr. Christopher Cahill (1999-2000, now Assistant Professor at George Washington University)

Dr. Sergey Krivovichev* (1999-2000, now Assistant Professor at St. Petersburg State University)

Dr. Paul W.O. Hoskin (2000-present)

\section{Graduate Students}

University of Notre Dame

Ms. Jennifer Jackson (M.S. 2000)

Mr. Yaping Li (Ph.D. expected 2001)

Mr. Andrew Locock (Ph.D. expected 2004)

Ms. Karrie-Ann Hughes (Ph.D. expected 2004)

University of Missouri-Rolla

Mr. C.W. Kim. (Ph.D. expected 2001)

*Dr. Krivovichev's stipend was provided by an NSF-NATO fellowship to work on the project; his research expenses were supported from the EMSP grant. 


\section{PUBLICATIONS}

\section{Peer-Reviewed Archival Journal Publications}

Buck, E.C., Wronkiewicz, D.J., Finn, P.A., and Bates, J.K., "A new uranyl oxide hydrate phase derived from spent fuel alteration", Journal of Nuclear Materials 249, $70-76$ (1997).

Burns, P.C. (2001): A new uranyl sulfate chain in the structure of uranopilite. Canadian Mineralogist (submitted).

Burns, P.C. \& Li, Yaping (2000): The structures of becquerelite and Sr-exchanged becquerelite. American Mineralogist (submitted).

Burns, P.C. (2001): A new uranyl silicate sheet in the structure of haiweeite and comparison to other uranyl silicates. Canadian Mineralogist (accepted).

Burns, P.C. (2000): A new uranyl phosphate chain in the structure of parsonsite. American Mineralogist 85, 801-805.

Burns, P.C. \& Hill, F.C. (2000): Implications of the synthesis and structure of the Sr analogue of curite. Canadian Mineralogist 38, 175-182.

Burns, P.C. \& Hill, F.C. (2000): A new uranyl sheet in $\mathrm{K}_{5}\left[\left(\mathrm{UO}_{2}\right)_{10} \mathrm{O}_{8}(\mathrm{OH})_{9}\right]\left(\mathrm{H}_{2} \mathrm{O}\right)$ : New insights into sheet anion-topologies. Canadian Mineralogist 38, 163-174.

Burns, P.C., Olson, R.A., Finch, R.J., Hanchar, J.M. and Thibault, Y. (2000): $\mathrm{KNa}_{3}\left(\mathrm{UO}_{2}\right)_{2}\left(\mathrm{Si}_{4} \mathrm{O}_{10}\right)_{2}\left(\mathrm{H}_{2} \mathrm{O}\right)_{4}$, a new compound formed during vapor hydration of an actinidebearing borosilicate waste glass. Journal of Nuclear Materials 278, 290-300.

Burns, P.C. (1999): The crystal chemistry of uranium. Reviews in Mineralogy 38, 23-90.

Burns, P.C. (1999): Cs boltwoodite obtained by ion exchange from single crystals: Implications for radionuclide release in a nuclear repository. Journal of Nuclear Materials 265, 218-223.

Burns, P.C. \& Finch, R.J. (1999): Wyartite: crystallographic evidence for the first pentavalenturanium mineral. American Mineralogist 84, 1456-1460.

Burns, P.C. (1998): The structure of boltwoodite and implications of solid-solution towards sodium boltwoodite. Canadian Mineralogist 36, 1069-1075.

Burns, P.C. (1998): The structure of compreignacite, $\mathrm{K}_{2}\left[\left(\mathrm{UO}_{2}\right)_{3} \mathrm{O}_{2}(\mathrm{OH})_{3}\right]_{2}\left(\mathrm{H}_{2} \mathrm{O}\right)_{7}$. Canadian Mineralogist 36, 1061-1067.

Cahill, C.L. \& Burns, P.C. (2001): Building unit and topological evolution in the hydrothermal DABCO-U-F system. Inorganic Chemistry 40, 1347-1351.

Cahill, C.L. \& Burns, P.C. (2000): The structure of agrinierite: A Sr-containing uranyl oxide hydrate mineral. American Mineralogist 85, 1294-1297.

Chen, Fanrong, Burns, P.C. \& Ewing, R.C. (2000): Near-field behavior of ${ }^{99}$ Tc during the oxidative alteration of spent nuclear fuel. Journal of Nuclear Materials 278, 225-232.

Chen, Fanrong, Burns, P.C. \& Ewing, R.C. (1999): ${ }^{79}$ Se: Geochemical and crystallo-chemical retardation mechanisms. Journal of Nuclear Materials 275, 81-94.

Fayek, M., Burns, P.C., Guo, Y.X. \& Ewing, R.C. (2000): Micro-structures associated with uraninite alteration. Journal of Nuclear Materials 277, 204-210.

Finch, R.J. \& Murakami, T. (1999): Systematic mineralogy and paragenesis of uranium minerals. In: Uranium: Mineralogy, Geochemistry and the Environment, by P.C. Burns and R.J. Finch Eds. Reviews in Mineralogy 38, 91-179 (Mineralogical Society of America, Washington, D.C.).

Finch, R.J., Hanchar, J.M., Hoskin, P.W.O. \& Burns, P.C. (2001): Rare earth elements in synthetic zircon. 2. A single-crystal X-ray study of xenotime substitution. American Mineralogist 86, 681-689.

Hanchar, J.M., Finch, R.J., Watson, E.B., Cherniak, D. (2001): Rare-earth elements in zircon. Part 1. Synthesis and rare-earth element and phosphorous doping. American Mineralogist 86 (in press). 
Hawthorne, F.C., Krivovichev, S.V. \& Burns, P.C. (2000): The crystal chemistry of sulfate minerals. Reviews in Mineralogy and Geochemistry 40, 1-112.

Hill, F.C. \& Burns, P.C. (1999): Structure of a synthetic Cs uranyl oxide hydrate and its relationship to compreignacite. Canadian Mineralogist 37, 1283-1288.

Jackson, J. M. \& Burns, P.C. (2001): A re-evaluation of the structure of weeksite, a uranyl silicate framework mineral. Canadian Mineralogist 39, 187-195.

Krivovichev, S.V., Cahill, C.L. \& Burns, P.C. (2001): Synthesis and crystal structures of two topologically related modifications of $\mathrm{Cs}_{2}\left[\left(\mathrm{UO}_{2}\right)_{2}\left(\mathrm{MoO}_{4}\right)_{3}\right]$. Inorganic Chemistry (submitted).

Krivovichev, S.V. \& Burns, P.C. (2001): Crystal chemistry of uranyl molybdates. III. New structural themes in $\mathrm{Na}_{6}\left[\left(\mathrm{UO}_{2}\right)_{2} \mathrm{O}\left(\mathrm{MoO}_{4}\right)_{4}\right], \mathrm{Na}_{6}\left[\left(\mathrm{UO}_{2}\right)\left(\mathrm{MoO}_{4}\right)_{4}\right]$ and $\mathrm{K}_{6}\left[\left(\mathrm{UO}_{2}\right)_{2} \mathrm{O}\left(\mathrm{MoO}_{4}\right)_{4}\right]$. Canadian Mineralogist 39, 207-214.

Krivovichev, S.V. \& Burns, P.C. (2001): Crystal chemistry of uranyl molybdates. IV. The structures of $M_{2}\left[\left(\mathrm{UO}_{2}\right)_{6}\left(\mathrm{MoO}_{4}\right)_{7}\left(\mathrm{H}_{2} \mathrm{O}\right)_{2}\right]\left(M=\mathrm{Cs}, \mathrm{NH}_{4}\right)$. Canadian Mineralogist 39, 215-226.

Krivovichev, S.V. \& Burns, P.C. (2000): Crystal chemistry of uranyl molybdates. II. The crystal structure of iriginite. Canadian Mineralogist 38, 847-851.

Krivovichev, S.V. \& Burns, P.C. (2000): Crystal chemistry of uranyl molybdates. I. The structure and formula of umohoite. Canadian Mineralogist 38, 717-726.

Li, Yaping \& Burns , P.C. (2001): The crystal structure of synthetic grimselite, $\mathrm{K}_{3} \mathrm{Na}\left[\left(\mathrm{UO}_{2}\right)\left(\mathrm{CO}_{3}\right)_{3}\right]\left(\mathrm{H}_{2} \mathrm{O}\right)$. Canadian Mineralogist (accepted).

Li, Yaping, Cahill, C.L. \& Burns , P.C. (2001): Synthesis and structural characterization and topological rearrangement of a novel open framework U-O material: $\left(\mathrm{NH}_{4}\right)_{3}\left(\mathrm{H}_{2} \mathrm{O}\right)_{2}\left\{\left[\left(\mathrm{UO}_{2}\right)_{10} \mathrm{O}_{10}(\mathrm{OH})\right]\left[\left(\mathrm{UO}_{4}\right)\left(\mathrm{H}_{2} \mathrm{O}\right)_{2}\right]\right\}$. Chemistry of Materials (accepted).

Li, Y., Krivovichev, S.V. \& Burns, P.C. (2001): The crystal structure of $\mathrm{Na}_{4}\left(\mathrm{UO}_{2}\right)\left(\mathrm{CO}_{3}\right)_{3}$ and its relationship to schröckingerite. Mineralogical Magazine 65, 285-292.

Li, Y. \& Burns, P.C. (2000): A new rare-earth element uranyl carbonate sheet in the structure of bijvoetite-(Y). Canadian Mineralogist 38, 153-162.

Li, Y., Krivovichev, S.V. \& Burns, P.C. (2000): The crystal structure of thornasite, $\mathrm{Na}_{12} \mathrm{Th}_{3}\left[\mathrm{Si}_{8} \mathrm{O}_{19}\right]_{4}\left(\mathrm{H}_{2} \mathrm{O}\right)_{18}$ : a novel interrupted silicate framework. American Mineralogist 85, 1521-1525.

Wronkiewicz, D.J. and Buck, E.C., "Uranium mineralogy and the geologic disposal of spent nuclear fuel", in Uranium Mineralogy, (R.J. Finch and P.C. Burns eds.) Reviews in Mineralogy Series, Mineralogical Society of America, vol. 38 Washington D.C., pp. 475-498 (1999).

\section{Refereed Symposium Proceedings}

Chen, F., Burns, P.C., \& Ewing, R.C. (1998): ${ }^{79}$ Se: Geochemical and crystallo-chemical retardation mechanisms. The Scientific Basis for Nuclear Waste Management XX. MRS Proceedings, 556, 1115-1122.

Finch, R.J., \& Buck, E.C. (1998): Synthesis and characterization of $\mathrm{Ba}\left[\left(\mathrm{UO}_{2}\right)_{5} \mathrm{MoO}_{6}(\mathrm{OH})_{6}\right] \cdot n \mathrm{H}_{2} \mathrm{O}$. Materials Research Society, Boston, MA, November 30 December 4, 1998. MRS 1998 Fall Meeting Abstracts volume 25, 723 (abstract)

Kim, C.W., Wronkiewicz, D.J., and Buck, E.C. "Potential incorporation of transuranics into uranium alteration phases," Scientific Basis for Nuclear Waste Management XXIII, Materials Res. Soc. Symp. Proc. (R.W. Smith and D.W. Shoesmith eds.) Vol. 608, pp. 47-54.

Kim, C.W. and Wronkiewicz, D.J., "Incorporation of radionuclides in the alteration phases of spent nuclear fuel", abstract, Migration '99, $7^{\text {th }}$ International Conference on the Chemistry and Migration Behavior of Actinides and Fission Products in the Geosphere, p. 20 (1999). 
Wronkiewicz, D.J., Bates, J.K., and Buck, E.C., "Grain boundary corrosion and alteration phase formation during the oxidative dissolution of $\mathrm{UO}_{2}$ pellets", in: Scientific Basis For Nuclear Waste Management XX. Material Res. Soc., Symp. Proc. (W.J. Gray and I.R. Triay eds.) Vol. 465, pp. 519-526 (1997).

\section{Refereed Conference Abstracts}

Burns , P.C. (2001): Structures of uranyl minerals and compounds containing tetrahedrally coordinated hexavalent cations. Goldschmidt Conference (invited).

Burns , P.C. (2000): Mineralogy: where we are and where we're going. Geoscience 2000 (Calgary).

Burns, P.C., Hill, F.C., Finch, R.J. \& Olson, R.A. (1999): Radionuclide retardation in uranyl silicate forming in a geological repository for nuclear waste. $G S A$ (Denver).

Burns, P.C. \& Finch, R.J. (1999): The structure of wyartite: Crystallographic evidence for the first pentavalent-uranium mineral. GAC-MAC (Sudbury).

Burns, P.C. (1998): Topological aspects of uranyl mineral structures. IMA (Toronto).

Cahill, C.L., Krivovichev, S.V, \& Burns, P.C., (2000): Novel open-framework uranyl molybdates. Abstracts of Papers of the American Chemical Society, 220: 463-INOR.

Cahill, C.L. \& Burns, P.C. (1999): The structure of agrinierite: a K-Ca-Sr uranyl oxide hydrate sheet of the $\alpha-\mathrm{U}_{3} \mathrm{O}_{8}$ type. $G S A$ (Denver).

Finch, R.J., Kropf, A.J. \& Hanchar, J.M. (2001): XAFS spectra of HREE in zircon. Goldschmidt Conference Special Session on Accessory Minerals: Equilibrium and Kinetic Properties and Applications. Roanoke, Virginia, May 20-24, 2001. Invited.

Finch, R.J., Hanchar, J.M., Hoskin, P.W.O. \& Burns, P.C. (1998): Rare earth elements in synthetic zircon: the roles of $\mathrm{P}$ and Li. GSA (Toronto).

Finch, R.J. et al. (2000): Accessory minerals and the alteration of nuclear-waste forms: Insights and comparisons. American Geophysical Union Spring Meeting, Washington, D.C. Invited.

Finch, R.J. et al. (2000): Actinide and lanthanide host phases formed during the corrosion of nuclear-waste forms. American Chemical Society National Meeting, San Francisco. Invited.

Hanchar, J.M., Finch, R.J., Watson, E.B. \& Hoskin, P.W.O. (2001): Towards a better understanding of rare earth element partition coefficients in zircon. European Union of Geochemistry; Special Session on Accessory Minerals: Equilibrium and Kinetic Properties and Applications. Roanoke, Virginia. Invited.

Hill, F.C. \& Burns, P.C. (1999): Cs ion exchange in boltwoodite. GSA (Denver).

Hill, F.C. \& Burns, P.C. (1999): The importance of uranyl silicates for the disposal of nuclear waste. GAC-MAC (Sudbury).

Hill, F.C. \& Burns, P.C. (1998): Investigations of the crystal chemistry of uranyl oxide hydrates. IMA (Toronto).

Hill, F.C. \& Burns, P.C. (1998): Chemical and structural diversity in the uranyl oxide hydrate system. GSA (Toronto).

Hoskin, P.W.O. \& Burns, P.C. (2001): Experimental evidence for retardation of ${ }^{135}$ Cs mobility in a nuclear repository by ion exchange into compreignacite. Goldschmidt Conference (accepted).

Jackson, J.M. \& Burns, P.C. (1999): The structure of weeksite: a potassium uranyl silicate hydrate. $G S A$ (Denver).

Jensen, K.A., Ewing, R.C. \& Burns, P.C. (2000): The role of sulfates during supergene weathering in the Oklo-Okélobondo uranium deposit. GSA (Reno). 
Kim, C.W. and Wronkiewicz, D.J., "Effects of secondary uranium minerals on the migration of radionuclides," abstract, Missouri Academy of Sciences, Spring Meeting (2000).

Kim, C.W., Wronkiewicz, D.J., and Buck, E.C. "Synthesis of $\mathrm{Ce}^{4+}$ and $\mathrm{Nd}^{3+}$-bearing ianthinite: Implications for the incorporation of $\mathrm{Pu}^{4+}$ and $\mathrm{Am}^{3+}$ into the alteration phases of spent nuclear fuel", abstract, Geological Society of America 1999 annual Fall Meeting, p. A-135 (1999).

Kim, C.W. and Wronkiewicz, D.J., "Incorporation of radionuclides in the alteration phases of spent nuclear fuel", abstract, Missouri Academy of Sciences, 1999 Spring Meeting (1999).

Kim, C.W. and Wronkiewicz, D.J., "Alteration phases of spent nuclear fuel", abstract, Missouri Academy of Sciences, 1998 Spring Meeting (1998).

Kim, C.W. \& Wronkiewicz, D.J. (1999): Incorporation of radionuclides in the alteration phases of spent nuclear fuel, abstract, Migration '99, $7^{\text {th }}$ International Conference on the Chemistry and Migration Behavior of Actinides and Fission Products in the Geosphere, p. 20.

Krivovichev, S.V. \& Burns , P.C. (2000): Crystal chemistry of uranyl molybdates: review of new structures studied using CCD detector. $A G U$ (Washington).

Li, Y., Krivovichev, S.V. \& Burns, P.C. (2000): The structure of $\mathrm{Na}_{4}\left(\mathrm{UO}_{2}\right)\left(\mathrm{CO}_{3}\right)_{3}$ and the environmental importance of uranyl carbonates. $A G U$ (Washington).

Li, Yaping \& Burns, P.C. (1999): A new REE-bearing uranyl carbonate sheet in the structure of bijvoetite. GSA (Denver).

Li, Yaping \& Burns, P.C. (1999): A single-crystal X-ray diffraction study of the crystal chemistry of curite. GAC-MAC (Sudbury).

Locock, A.J. \& Burns, P.C. (2001): Investigations of the autunite and meta-autunite groups: Crystal structure refinements of synthetic zeunerite, metatorbernite, trögerite and chernikovite. Goldschmidt Conference (accepted).

Scott, S.M. \& Burns, P.C. (2000): A single-crystal study of ion exchange in compreignacite. $A G U$ (Washington).

Wronkiewicz, D.J., "Uranium mineralogy and the geologic disposal of spent nuclear fuel", abstract, Geological Society of America 1999 annual fall meeting, p. A-135 (1999).

Wronkiewicz, D.J., "The role of natural analogues in evaluating the long-term corrosion behavior of nuclear waste forms", abstract, Missouri Academy of Sciences, 1999 Spring Meeting (1999).

\section{Other Publications}

Burns, P.C., Finch, R.J., and Wronkiewicz, D.J., "Direct investigations of the immobilization of radionuclides in the alteration phases of spent nuclear fuel", Environmental Management Science Program Workshop, July 27-30, 1998; Chicago, IL, p. 404-406 (1998).

Finn, P.A., Wronkiewicz, D.J., Finch, R.J., Hoh, J.C., Mertz, C., Emery, J.W., Buck, E.C., Fortner, J., Wolf, S.F., Neimark, L.A., Bates, J.K., "Yucca Mountain Project - Argonne National Laboratory, Annual Progress Report, FY 1997 for Activity WP 1221: Unsaturated Drip Condition Testing of Spent Fuel and Unsaturated Dissolution Tests of Glass", Argonne National Laboratory Report, ANL-98/12 152 p. (1998).

Kropf, A.J., Finch, R.J., Conner, C., Karanfil, C., Chapman, L.D., Serge, C. \& Terry, J. (2001): A Silicon Bent Crystal Analyzer as an Energy Bandpass Filter for Fluorescence XAFS. Advanced Photon Source Activity Report 2000. April 2001.

Finch, R.J., Kropf, A.J. \& Hanchar, J.M. (2001): XAFS spectra of HREE in zircon Advanced Photon Source Activity Report 2000. April 2001. 


\section{Invited Lectures (Short Courses)}

Prof. Burns presented "The crystal chemistry of sulfates" at a Mineralogical Society of America Short Course in November, 2000.

Prof. Burns presented "The crystal chemistry of uranium" at a Mineralogical Society of America Short Course in October, 1999

Prof. Wronkiewicz presented "Uranium mineralogy and the geologic disposal of spent nuclear fuel" at a Mineralogical Society of America Short Course in October, 1999

Dr. Finch presented "Systematic mineralogy and paragenesis of uranium minerals" at a Mineralogical Society of America Short Course in October, 1999

\section{Invited Lectures (non-refereed)}

Prof. Burns has presented lectures concerning aspects of the EMSP-funded research at the following organizations:

Washington University in Saint Louis 2000

Miami University of Ohio 2000

University of Illinois-Urbana 2000

Idaho National Engineering and Environmental Laboratory 2000

University of Windsor 1999

Indiana University Purdue University - Indianapolis 1999

Duke University 1998

Dr. Finch has presented lectures concerning aspects of the EMSP-funded research at the following organizations:

University of Missouri-Rolla 2000

Purdue University 2000

\section{Publication of RIM volume "Uranium: Mineralogy, Geochemistry and the Environment"}

During 1997 Burns and Finch undertook the preparation of a Reviews in Mineralogy volume concerning most aspects of $U$ in natural systems. Volume 38, entitled "Uranium:

Mineralogy, Geochemistry and the Environment" was published in the fall of 1999. Burns and Finch also convened, and taught a portion of, a short course of the same title with 79 attendees. The volume has 14 chapters (including three by the PIs) that deal with many aspects of $U$ in natural systems that are relevant to disposal of spent fuel in a geological repository.

\section{Publication of Scientific Basis for Nuclear Waste Management Volume 556}

In 1998, D.J. Wronkiewicz chaired the Scientific Basis for Nuclear Waste Management Materials Research Society meeting with co-chair J. Lee. Volume 556, by name of the title, was published in 1999. The volume contains 162 papers dealing with nuclear waste, including 17 that are related to the geologic disposal of spent fuel. 


\section{INTERACTIONS}

The PIs of this project have attended many professional conferences (there are more than 30 refereed abstracts concerning this research), have organized a special session at the Geological Society of America conference in 1999 concerning the mineralogy and geochemistry of uranium, and have organized and taught portions of a Mineralogical Society of America Short Course entitled "Uranium: Mineralogy, Geochemistry and the Environment". They have presented numerous seminars at National Laboratories and Universities throughout the country that involve aspects of this research. Publications and abstract titles are listed above.

\section{Interactions with National Spent Fuel Program}

The National Spent Fuel Program, located at INEEL, is responsible for the DOE's spent nuclear fuel, and is thus the end-user of much of our research. The PI's contact with the National Spent Fuel Program has mainly been through Colleen Shelton-Davis at INEEL. Several telephone conversations culminated in Prof. Burns visiting INEEL for two days in January 2000, where he presented the lecture "The Crystal Chemistry of Uranium: Applications to the Disposal of Spent Nuclear Fuel" to 30 scientists. Prof. Burns has engaged in detailed discussions with Colleen Shelton-Davis concerning the results of the research, and how recent findings may impact upon the goals of the National Spent Fuel Program. Conversations have also focused on how to maximize the impact of future research done as part of this and future grants. Reprints of all published articles have been provided to members of the National Spent Fuel Program.

\section{Collaborations with Russian Scientists}

In October 1999, by invitation of the Under Secretary of Energy, Prof. Burns was a member of a delegation of 16 American scientists that visited the Russian Academy of Sciences in Moscow to participate in a workshop concerning the geological disposal of nuclear waste. He presented a seminar that emphasized the importance of uranium mineralogy for understanding the evolution of a geological repository for nuclear waste.

Dr. Sergey Krivovichev, from Saint Petersburg State University in Saint Petersburg, Russia, is an active researcher in this EMSP project. He was employed by the University of Notre Dame as a Postdoctoral Research Associate under the supervision of Prof. P.C. Burns. His salary was funded through an NSF-NATO grant (DGE99-03354). Dr. Krivovichev has since returned to Saint Petersburg State University where he is an assistant professor. We have recently been awarded a NATO Collaborative Linkage Grant under the title "Investigations of incorporation of toxic metals and radionuclides into structures of secondary minerals" which will permit further collaborations. It provides funds for Drs. Krivovichev and Filatov to visit Notre Dame in the summer of 2001 to conduct experiments, and Prof. Burns and Prof. Cahill (George Washington University, former post-doc under EMSP at Notre Dame) to visit Saint Petersburg later in the year to further collaborations.

\section{Collaborations with University of Michigan}

Prof. Burns' research group has extensively collaborated with Prof. Rodney Ewing's group in the Department of Nuclear Engineering at the University of Michigan. Prof. Ewing is the PI on an EMSP project that involves assessing the long-term role of uranium minerals in the evolution of a geological repository for nuclear waste. The ongoing collaboration largely 
involves developing an understanding of radionuclide incorporation mechanisms into the structures of uranyl minerals, and has resulted in several co-authored archival journal papers.

\section{FUTURE WORK}

Research reviewed in this report continues under the renewal grant 73691. Full details of future work are given in the proposal on file. In short, our ongoing research efforts will focus on (1) experimentally verifying and quantifying the uptake of Np-237, Se-79, Pu-239, Pu-242 and Am-241 by uranyl alteration phases, resulting in data that is appropriate for consideration in performance assessment models, (2) verification of the theoretically predicted exclusion of Tc-99 from uranyl alteration phases, (3) theoretical and experimental investigations of the uptake of I129 by uranyl alteration phases, (4) studies of the retention of radionuclides in uranyl phases during phase alteration, (5) investigations of means of promoting the precipitation of radionuclide-bearing uranyl phases in a backfill setting, (6) continued development of the structural hierarchy of uranyl phases, including investigations of the relations between the structures and stabilities of uranyl phases, (7) continued study of the newly discovered ion exchange properties of uranyl phases, (8) synthesis and characterization of uranyl phases containing $\mathrm{Np}$ and $\mathrm{Pu}$, and (9) studies of the alteration of uranium metal spent fuel. The proposed research will provide a more realistic estimate of the rate of radionuclide migration from the near field environment. An accurate assessment of realistic radionuclide solubilities in the repository will allow for the development of an effective and cost-efficient engineered barrier system. 


\section{LITERATURE CITED}

Anikina, L.I. \& Makarov, E.S. (1961): The unit cell of umohoite, $\mathrm{UO}_{2} \mathrm{MoO}_{4} 4 \mathrm{H}_{2} \mathrm{O}$. Doklady Akademii Nauk SSSR 137, 942-943 (in Russian).

Baturin, S.V. \& Sidorenko, G.A. (1985): Crystal structure of weeksite $\left.\mathrm{K}_{0.62} \mathrm{Na}_{0.38}\right)_{2}\left(\mathrm{UO}_{2}\right)_{2}\left[\mathrm{Si}_{5} \mathrm{O}_{13}\right] .3 \mathrm{H}_{2} \mathrm{O}$. Soviet Physics Doklady 30, 435-437.

Burakov, B.E., Strykanova, E.E. and Anderson, E.B. (1999) Secondary uranium minerals on the surface of Chernobyl "lava". Mat. Res. Soc. Symp. Proc., 465, 1309-11.

Buck, E.C., Wronkiewicz, D.J., Finn, P.A., \& Bates, J.K. (1997): A new uranyl oxide hydrate phase derived from spent fuel alteration. J. Nucl. Mater. 249, 70-76.

Buck E.C., Finch R.J., Finn P.A., Bates J.K. (1998) Retention of neptunium in uranyl alteration phases formed during spent fuel corrosion. In Scientific Basis for Nuclear Waste Management XXI (I.A. McKinley \& C. McCombie, eds.) Materials Research Society Symposium Proceedings 506, pp. 87-94.

Burns, P.C. (2001a): A new uranyl silicate sheet in the structure of haiweeite and comparison to other uranyl silicates. Can. Mineral. (accepted).

Burns, P.C. (2001b): A new uranyl sulfate chain in the structure of uranopilite. Canadian Mineralogist (submitted).

Burns, P.C. (1999a): The crystal chemistry of uranium. Rev. Mineral. 38, $23-90$.

Burns, P.C. (1999b): Cs boltwoodite obtained by ion exchange from single crystals: Implications for radionuclide release in a nuclear repository. J. Nucl. Mater. 265, 218-223.

Burns, P.C. (1998a): CCD X-ray area detectors applied to the analysis of mineral structures. Can. Mineral. 36, 847-853.

Burns, P.C. (1998b): The structure of boltwoodite and implications of solid-solution towards sodium boltwoodite. Can. Mineral. 36, 1069-1075.

Burns, P.C. (1998c): The structure of compreignacite, $\mathrm{K}_{2}\left[\left(\mathrm{UO}_{2}\right)_{3} \mathrm{O}_{2}(\mathrm{OH})_{3}\right]_{2}\left(\mathrm{H}_{2} \mathrm{O}\right)_{7}$. Can. Mineral. 36, 1061-1067.

Burns, P.C., Finch, R.J., Hawthorne, F.C., Miller, M.L., \& Ewing, R.C. (1997): The crystal structure of ianthinite, $\left[\mathrm{U}^{4+}{ }_{2}\left(\mathrm{UO}_{2}\right)_{4} \mathrm{O}_{6}(\mathrm{OH})_{4}\left(\mathrm{H}_{2} \mathrm{O}\right)_{4}\right]\left(\mathrm{H}_{2} \mathrm{O}\right)_{5}$ : A possible phase for $\mathrm{Pu}^{4+}$ incorporation during the oxidation of spent nuclear fuel. J. Nucl. Mater. 249, 199-206.

Burns, P.C. \& Finch, R.J. (1999): Wyartite: crystallographic evidence for the first pentavalenturanium mineral. Am. Mineral. 84, 1456-1460.

Burns, P.C. \& Hill, F.C. (2000a): A new uranyl sheet in $\mathrm{K}_{5}\left[\left(\mathrm{UO}_{2}\right)_{10} \mathrm{O}_{8}(\mathrm{OH})_{9}\right]\left(\mathrm{H}_{2} \mathrm{O}\right)$ : New insights into sheet anion-topologies. Can. Mineral. 38, 163-174.

Burns, P.C. \& Hill, F.C. (2000b): Implications of the synthesis and structure of the Sranalogue of curite. Can. Mineral. 38, 175-182.

Burns, P.C., Miller, M.L. \& Ewing, R.C. (1996): $\mathrm{U}^{6+}$ minerals and inorganic phases: a comparison and hierarchy of structures. Can. Mineral. 34, 845-880.

Burns, P.C., Olson, R.A., Finch, R.J., Hanchar, J.M. \& Thibault, Y. (2000a): $\mathrm{KNa}_{3}\left(\mathrm{UO}_{2}\right)_{2}\left(\mathrm{Si}_{4} \mathrm{O}_{10}\right)_{2}\left(\mathrm{H}_{2} \mathrm{O}\right)_{4}$, a new compound formed during vapor hydration of an actinidebearing borosilic ate waste glass. J. Nucl. Mater. 278, 290-300.

Cahill, C.L. \& Burns, P.C. (2000): The structure of agrinierite: A Sr-containing uranyl oxide hydrate mineral. American Mineralogist 85, 1294-1297.

Chen, Fanrong, Burns, P.C. \& Ewing, R.C. (2000): Near-field behavior of ${ }^{99}$ Tc during the oxidative alteration of spent nuclear fuel. J. Nucl. Mater. 278, 225-232.

Chen, Fanrong, Burns, P.C. \& Ewing, R.C. (1999): ${ }^{79}$ Se: Geochemical and crystallo-chemical retardation mechanisms. J. Nucl. Mater. 275, 81-94.

CRWMS M\&O 1998. Total System Performance Assessment - Viability Assessment (TSPA-VA) Analyses Technical Basis Document. B00000000-01717-4301-00004 REV 01. Las Vegas, Nevada 
Finch, R.J., Buck, E.C., Finn, P.A. \& Bates, J.K. (1999): Oxidative corrosion of spent UO2 fuel in vapor and dripping groundwater at $90^{\circ} \mathrm{C}$. In: Scientific Basis for Nuclear Waste Management XXII (D.J. Wronkiewicz and J.H. Lee, editors) Materials Research Society Symposium Proceedings 556, 431-438.

Finch R.J. \& E.C. Buck, P (1998) Synthesis and characterization of $\mathrm{Ba}\left[\left(\mathrm{UO}_{2}\right)_{5} \mathrm{MoO}_{6}(\mathrm{OH})_{6}\right] \cdot n \mathrm{H}_{2} \mathrm{O}$. Materials Research Society, Boston, MA, November 30 December 4, 1998.

Finch, R.J. \& Ewing, R.C. (1992): The corrosion of uraninite under oxidizing conditions. J. Nucl. Mater. 190, 133-156.

Finn, P.A., Buck, E.C., Gong, M., Hoh, J.C., Emery, J.W., Hafenrichter, L.D., \& Bates, J.K. (1994): Colloidal products and actinide species in leachate from spent nuclear fuel. Radiochim. Acta . 66/67, 197-203.

Finn, P.A., Wolf, S.F., Leonard, R.A., Finch, R.J., \& Buck, E.C. (1999): Radionuclide release rates and concentrations in unsaturated tests with oxide fuels - first 4.8 years. Presented at the seventh international conference on the Chemistry and Migration Behavior of Actinides and Fission Products in the Geosphere, Incline Village, Lake Tahoe, Nevada, USA, September 26 - October 1, 1999, Abstracts vol. 7, 17.

Finn, P.A., Hoh, J.C., Wolf, S.F., Slater, S.A. \& Bates, J.K. (1996): The release of uranium, plutonium, cesium, strontium, technetium and iodine from spent fuel under unsaturated conditions. Radiochim. Acta 74, 65-71.

Frondel, C. (1956): Mineral composition of gummite. Am. Mineral. 41, 539-568.

Hill, F.C. \& Burns, P.C. (1999a): Structure of a synthetic Cs uranyl oxide hydrate and its relationship to compreignacite. Can. Mineral. 37, 1283-1288.

Hill, F.C. \& Burns, P.C. (1999b): Cs ion exchange in boltwoodite. GSA (Denver).

Integrated Data Base Report - 1994 (1995) US Department of Energy Report DOE/RW-0006, Rev. 11.

Jackson, Jennifer M. \& Burns, P.C. (2001): A re-evaluation of the structure of weeksite, a uranyl silicate framework mineral. Canadian Mineralogist 39, 187-195.

Krivovichev, S.V. \& Burns, P.C. (2001a): Crystal chemistry of uranyl molybdates. III. New structural themes in $\mathrm{Na}_{6}\left[\left(\mathrm{UO}_{2}\right)_{2} \mathrm{O}\left(\mathrm{MoO}_{4}\right)_{4}\right], \mathrm{Na}_{6}\left[\left(\mathrm{UO}_{2}\right)\left(\mathrm{MoO}_{4}\right)_{4}\right]$ and $\mathrm{K}_{6}\left[\left(\mathrm{UO}_{2}\right)_{2} \mathrm{O}\left(\mathrm{MoO}_{4}\right)_{4}\right]$. Canadian Mineralogist (in press).

Krivovichev, S.V. \& Burns, P.C. (2001b): Crystal chemistry of uranyl molybdates. IV. The structures of $M_{2}\left[\left(\mathrm{UO}_{2}\right)_{6}\left(\mathrm{MoO}_{4}\right)_{7}\left(\mathrm{H}_{2} \mathrm{O}\right)_{2}\right]\left(M=\mathrm{Cs}, \mathrm{NH}_{4}\right)$. Canadian Mineralogist (in press).

Krivovichev, S.V. \& Burns, P.C. (2000b): Crystal chemistry of uranyl molybdates. II. The crystal structure of iriginite. Canadian Mineralogist 38, 847-851.

Krivovichev, S.V. \& Burns, P.C. (2000a): Crystal chemistry of uranyl molybdates. I. The structure and formula of umohoite. Canadian Mineralogist 38, 717-726.

Li, Yaping \& Burns , P.C. (2001): The crystal structure of synthetic grimselite, $\mathrm{K}_{3} \mathrm{Na}\left[\left(\mathrm{UO}_{2}\right)\left(\mathrm{CO}_{3}\right)_{3}\right]\left(\mathrm{H}_{2} \mathrm{O}\right)$. Canadian Mineralogist (accepted).

Li, Y., Krivovichev, S.V. \& Burns, P.C. (2001): The crystal structure of $\mathrm{Na}_{4}\left(\mathrm{UO}_{2}\right)\left(\mathrm{CO}_{3}\right)_{3}$ and its relationship to schröckingerite. Mineralogical Magazine 65, 285-292.

Li, Y. \& Burns, P.C. (2000): A new rare-earth element uranyl carbonate sheet in the structure of bijvoetite-(Y). Canadian Mineralogist 38, 153-162.

Makarov, E.S. \& Anikina, L.I. (1963): The crystal structure of umohoite $\left[\mathrm{UMoO}_{6}\left(\mathrm{H}_{2} \mathrm{O}\right)_{2}\right] 2 \mathrm{H}_{2} \mathrm{O}$. Geokhimiya 1, 15-21.

Nitsche, H. et al. (1993): Measured solubilities and speciation of $\mathrm{Np}, \mathrm{Pu}$, and $\mathrm{Am}$ in a typical groundwater (J-13) from the Yucca Mountain Region. Los Alamos NationalLaboratory Report LA-12562-MS.

Nitsche, H. et al. (1995): Solubility and speciation results from over- and undersaturation experiments on $\mathrm{Np}, \mathrm{Pu}$, and Am in water from Yucca Mountain Region Well UE-25p\#1. Los Alamos National Laboratory Report LA-13017-MS. 
Pearcy, E.C., Prikryl, J.D., Murphy, W.M., \& Leslie, B.W. (1994): Alteration of uraninite from the Nopal I deposit, Pena Blanca District, Chihuahua, Mexico, compared to degradation of spent nuclear fuel in the proposed U.S. high-level nuclear waste repository at Yucca Mountain Nevada. Applied Geochem. 9, 713-732.

Rastsvetaeva, R.K., Arakcheeva, A.V., Pushcharovskii, D. Yu., Atencio, D., \& Menezes Filho, L.A.D. (1997): A new silicon band in the haiweete structure. Crystallogr. Rep. 42, 927-933.

Serezhkin, V.N., Yefremov, V.A. \& Trunov, V. K. (1981): More precise crystal structure of iriginite. Geokhimiya 1981(6), 911-916.

Stohl, F.V. \& Smith, D.K. (1981): The crystal chemistry of the uranyl silicate minerals. Am. Mineral. 66, 610-625.

Wilson, C.N. (1990): Results from NNWSI series 3 spent fuel dissolution tests, Pacific Northwestern Laboratory Report PNL-7170, Richland.

Wronkiewicz, D.J., Bates, J.K., Gerding, T.J., Veleckis, E. \& Tani, B.S. (1992): Uranium release and secondary phase formation during unsaturated testing of $\mathrm{UO}_{2}$ at $90^{\circ} \mathrm{C}$. J. Nucl. Mater. 190, 107-127.

Wronkiewicz, D.J., Bates, J.K., Wolf, S.F. \& Buck, Edgar C. (1996): Ten-year results from unsaturated drip tests with $\mathrm{UO}_{2}$ at $90^{\circ} \mathrm{C}$ : implications for the corrosion of spent nuclear fuel. $J$. Nucl. Mater. 238, 78-95. 